\title{
INVESTIGATION OF REDISTRIBUTION OF PILE FOUNDATION FORCES UNDER SUCCESSIVE LOADING OF ITS ELEMENTS
}

\author{
Vladimir SEDIN ${ }^{1}$, Kateryna BIKUS, Vladislav KOVBA \\ PSACEA, Foundation Engineering Department, Dnipro, Ukraine
}

\begin{abstract}
Redistribution of pile foundation forces under successive loading of its elements was investigated under laboratory conditions. A segment of pile foundation model was taken for use in the case study. Load tests on the pile foundation model segment, without joining its elements (pile and plate, which turns into grillage) and based on different combinations of static loadings were conducted. This proved that the loading of a plate causes skin friction on some length of the pile side surface as well as providing additional loading and settlement. Test results have shown that application of successive elements enables the foundation to carry loads up to $13 \%$ higher than in the case of a standard pile foundation loading with the same settlement rates.
\end{abstract}

Keywords: segment of pile foundation, plate not joining a pile, additional skin friction, successive loading.

\section{INTRODUCTION}

Piled raft foundations under the entire structure or the most loaded superstructures are typically designed for high rise buildings. Construction and maintenance of standard pile foundations has two extreme aspects: first, grillage is not used in the maintenance period due to soft soil settlement and the presence of a hollow space underneath it; secondly, the grillage provides additional bearing capacity reserves, which are not used in the maintenance period, since the structure preconditions

\footnotetext{
${ }^{1}$ Corresponding author: PSACEA, Foundation Engineering Department, Chernishevskogo st $24^{\mathrm{A}}$ Dnipro, Ukraine, e-mail: geotecprof @ gmail.com, tel.+380661418555
} 
some single settlement rate, but pile foundation elements (prop heel support bearing along side surface and under the grillage) are involved under different settlement rates. Professor I. Boyko emphasizes that this system of pile foundation could not be in effect simultaneously and causes over-expenditure in foundation construction [3].

Thus, the geotechnical engineer, when creating a pile foundation, should constantly balance a high reliability rate during the whole maintenance period taking into account the maximum potential of the subsurface ground. Nowadays, quite an efficient solution to this problem in many countries is to use pile foundations and activate all their elements, as well as controlling stress and strain in their bases [2, 4-8, 9]. In terms of engineering, it is possible to achieve this by successive loading of a plate not joining a pile. This process was investigated by such scientists as Gonzalez F., Brandl H. etc. Loading of these constructions is inevitably connected with pile settlements by means of additional skin frictions on some length of a pile side surface and was proved in the scientific papers of Bakholdin B.V., Berman V.I., Fellenius B.H., Bozozuk M., Correa J.J., Rodriguez J.F. $[2,4,6]$ etc.

Since geotechnical construction is a field which is potentially full of natural soil and subsurface resources, mobilization of the high bearing capacity of pile foundations is currently of primary importance.

\section{PURPOSE}

According to previous numerical modeling of stress and strain states [1] of pile foundation bases (first, separate plate loading and then simultaneous grillage loading), pile settlement was evident due to additional skin frictions. The purpose of this research is to investigate how the forces in pile foundations are changed according to loading of successive elements and preceding static pile loading (before joining a plate) under laboratory conditions. In order to implement the case study, it is necessary to conduct three load tests of pile foundation model segment without joining its elements (pile and plate, which turns into grillage).

\section{PLANNING AND TECHNIQUES OF MODEL INVESTIGATION}

Redistribution of pile foundation forces under successive loading of its elements under laboratory conditions was investigated. A segment of pile foundation model was taken as a sample. Pile model diameter was $25 \mathrm{~mm}$, its length $-640 \mathrm{~mm}$ (Fig. 1a). A tank is a metal cylinder which consists of the following elements: a split case of circular segments and sheet steel bottom (Fig. 1). Internal sizes of the tank are $500 \times 800 \mathrm{~mm}$ (Fig. 1). This was filled with sand soil layers, $20 \mathrm{~mm}$ 
each, and tamped with 3-kilo manual stamper (dry soil density $\rho_{\mathrm{d}}=1,41 \mathrm{~g} / \mathrm{cm}^{3}$ with moisture content value $-\mathrm{W}=0,09)$.

Soil density was controlled by cutting the soil samples into slices.

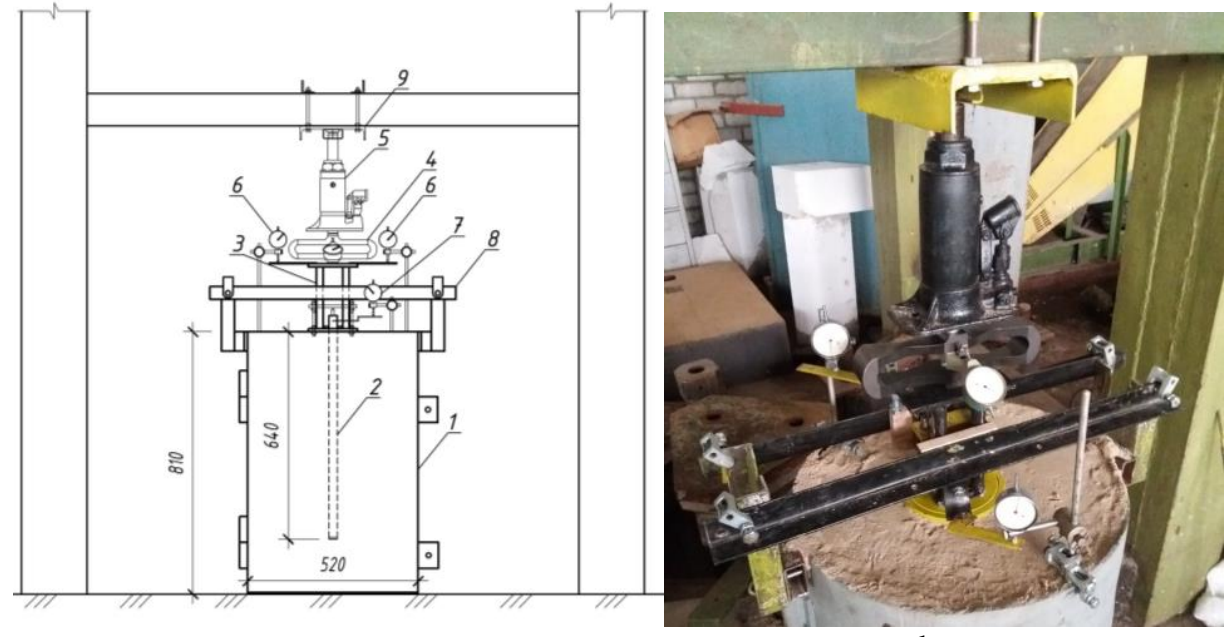

a

b

Fig. 1. Test facility: a - test facility layout: 1 - cylinder-shaped tank; 2 - pile model;

3 - plate segment model; 4 - mechanical load gauge; 5 - hydraulic jack;

6 - deflectometer (to identify plate settlement); 7 - indicators (to identify pile settlement); 8 - racks for balanced plate settlement; 9 - fixing jack support (12 mm plate); $b$ - photo

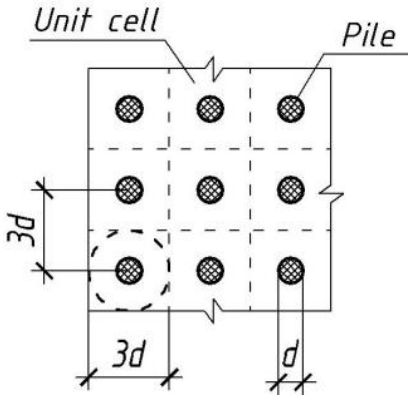

a

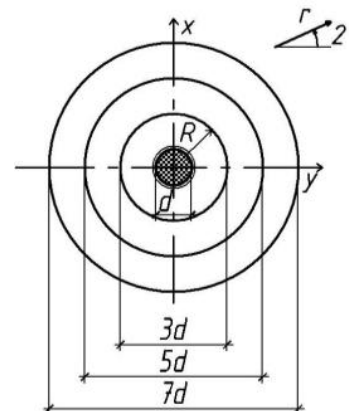

b

Fig. 2. Soil body with regularly placed piles and unit cell model (a) plate segment constructions (b): $\mathrm{d}$ - pile diameter, $3 d, 5 d$ i $7 d$ - unit cell size (distance between piles)

$$
\mathrm{R} \text { - unit cell radius }
$$

Nominally, in accordance with the applied method [10] in plan, a square unit cell with a pile inside was separated in the pile foundation. Its outer perimeter was changed into an $\mathrm{R}$ radius circle (Fig. 2a). Thus, three size variants of plate 
segment constructions with openings for placing a pile model (Fig. 2a) were made.

Taking into account a pile diameter $(d)$ and conditional distance between piles, the accepted diameters of plate segments are $3 d, 5 d$ and $7 d$ (Fig. 2b). Respectively, if diameter is $75-\mathrm{mm}$ - soil loading area is $38,4 \mathrm{~cm}^{2}$ (Fig. 3a), 125$\mathrm{mm}$ diameter - soil loading area is $116,9 \mathrm{~cm}^{2}$ (Fig. 3b), $175-\mathrm{mm}$ diameter- soil loading area is $234,7 \mathrm{~cm}^{2}$ (Fig. 3c).

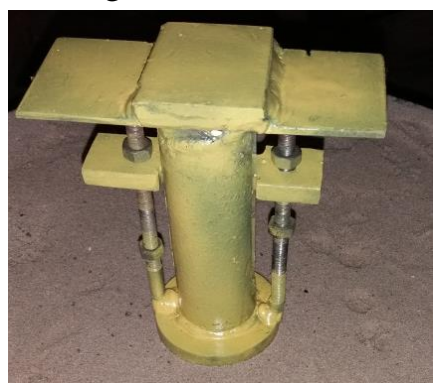

a

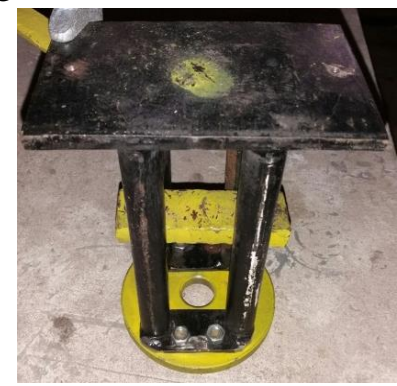

b

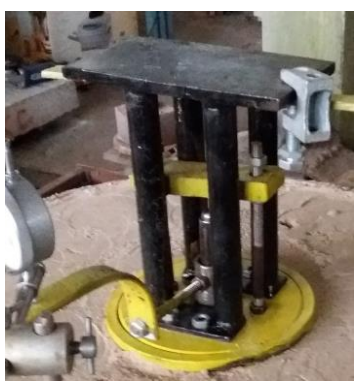

c

Fig. 3. The photo of plate model segments depending on pile diameter $(d)$ and conditional distance between piles: $\mathrm{a}-3 d,(75 \mathrm{~mm}) ; \mathrm{b}-5 d,(125 \mathrm{~mm}) ; \mathrm{c}-7 d(175 \mathrm{~mm})$

Static loading of the plate model segment was transferred by means of 5-ton load hydraulic jack, which was mounted on a plate and rested upon a system of stop bars of anchor-type stand (Fig. 1a). The load applied on the plate segment was monitored at each stage with mechanical load gauges. Their sensitivity rate was not more than $0,02 \%$ from the highest measurement mark and they were installed between the hydraulic jack and a plate. Each load stage lasted until relative stabilization of pile settlement.

The readings were taken immediately after load application and repeatedly at 30 min intervals. Vertical settlements of plate segment were recorded with the help of two deflectometers with $0,01 \mathrm{~mm}$ accuracy installed in stop accuracy devices. Pile settlement was also recorded with a deflectometer (Fig. 1a). The arithmetical average of readings recorded by two devices was taken as the measured value of pile deformation.

\section{TEST PROGRAM DEFINITION}

Three sets of static load tests based on combinations of loads were conducted (Fig. 3). In the $\mathrm{I}^{\text {st }}$ and $\mathrm{III}^{\text {rd }}$ tests, the elements of pile foundation segment were successively loaded - first, a plate not joining a pile was loaded and after that a plate joining a pile (Fig. $3 \mathrm{~b}$, d). In the III $^{\text {rd }}$ test, a pile not joining a plate was additionally loaded (Fig. 3c). 


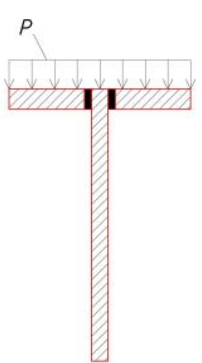

a

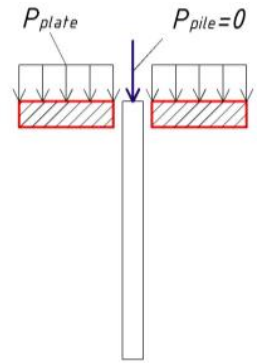

b

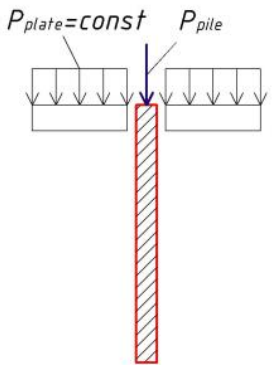

$\mathrm{c}$

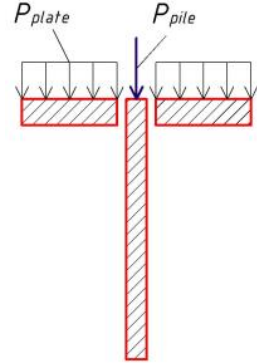

d

Fig. 4. Layout of load combinations of pile foundation elements: $a-1^{\text {st }}$ test; $b-1^{\text {st }}$ stage of II ${ }^{\text {nd }}$ and III ${ }^{\text {rd }}$ tests; $c-2^{\text {nd }}$ stage of III ${ }^{\text {rd }}$ test; $d-2^{\text {nd }}$ stage of II $^{\text {nd }}$ test and $3^{\text {rd }}$ stage of III ${ }^{\text {rd }}$ test

\subsection{First test - loading of a plate joining a pile.}

The $\mathrm{I}^{\text {st }}$ test had 1 stage (Fig. 4a); A plate joining a pile. The strain and stress state of such segment simulates the performance of a standard piled foundation segment and test results are taken as $100 \%$ to assess the performance of further tests. Fig. 5. shows dependence of plate segments settlement on loading $S=f(P)$ for three plate diameters based on observations concerning settlements of pile foundation segments.

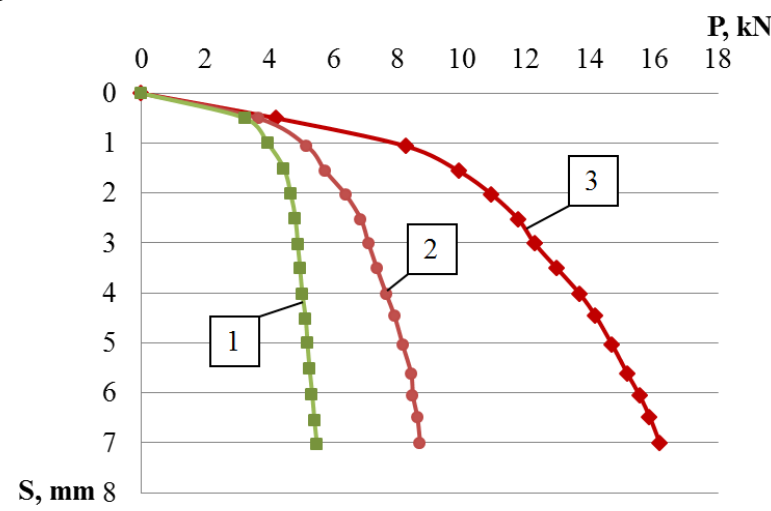

Fig. 5. Graph "Loading- Settlement" 1st stage of test for three different sizes of plate segments: $1-75 \mathrm{~mm} ; 2-125 \mathrm{~mm} ; 3-175 \mathrm{~mm}$

\subsection{Second test - loading of a plate segment: first, a plate not joining a pile and second, a plate joining a pile.}

The $\mathrm{II}^{\text {nd }}$ test run included two stages (Fig. $4 \mathrm{~b}, \mathrm{c}$ ). At the $1^{\text {st }}$ stage, a plate segment not joining a pile was loaded. Settlements are $S_{\text {plate }} \approx 2 \mathrm{~mm}$ (Fig. $4 \mathrm{~b}$ ). At the $2^{\text {nd }}$ stage, with the load applied at the $1^{\text {st }}$ stage, a plate joining a pile was added. Thus, a plate segment joining a pile was loaded (Fig. $4 \mathrm{~b}$ ). The $\mathrm{II}^{\text {nd }}$ test can be considered 
as a plate on pile-reinforced soil base (a pile is a reinforcement element first and second, a foundation construction element).

Fig. 6 shows the dependence graph $S=f(P)$ in the $\mathrm{II}^{\text {nd }}$ test run for three diameter types of plate segments.

The curves (before the vertical dashed-line) on the graph refer to the $1^{\text {st }}$ stage: settlement of a plate segment $\mathrm{S}_{\text {plate }} \approx 2 \mathrm{~mm}$ under loading $\mathrm{P}_{\text {plate }}=1,31 \mathrm{\kappa N}$ for a 75 mm plate (Fig. 6a); $P_{\text {plate }}=4,85 \mathrm{kN}$ for a $125-\mathrm{mm}$ plate (Fig. $6 \mathrm{~b}$ ); $\mathrm{P}_{\text {plate }}=9,87 \mathrm{kN}$ for a $175-\mathrm{mm}$ plate (Fig. 6c). The curves (after the vertical dashed-line) refer to the $2^{\text {nd }}$ stage (settlement of foundation segment linked to a pile for collaboration). Test runs for all diameter types of plate segments were conducted until maximum settlement was reached equal: $S_{\text {plate+pile, } \max } \approx 7 \mathrm{~mm}$ under maximum loading $P_{\text {plate+pile, } \max }=5,72 \mathrm{kN}$ for $75 \mathrm{~mm}$ plate (Fig. 6a); $\mathrm{P}_{\text {plate+pile, } \max }=9,46 \mathrm{kN}$ for $125 \mathrm{~mm}$

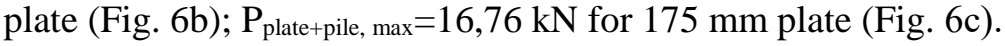

a)

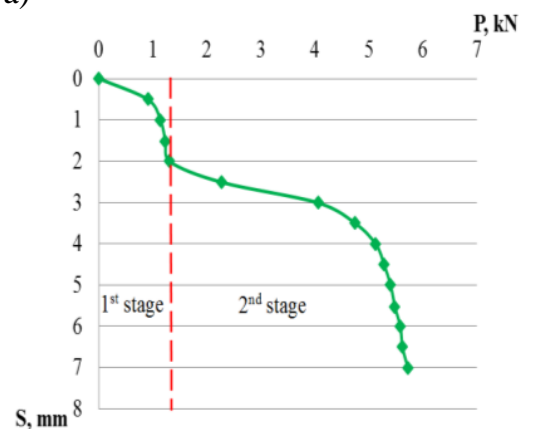

b)

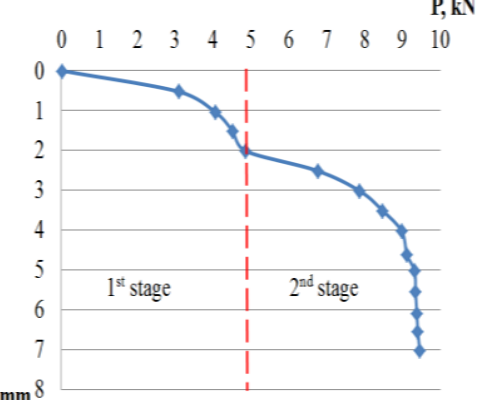

c)

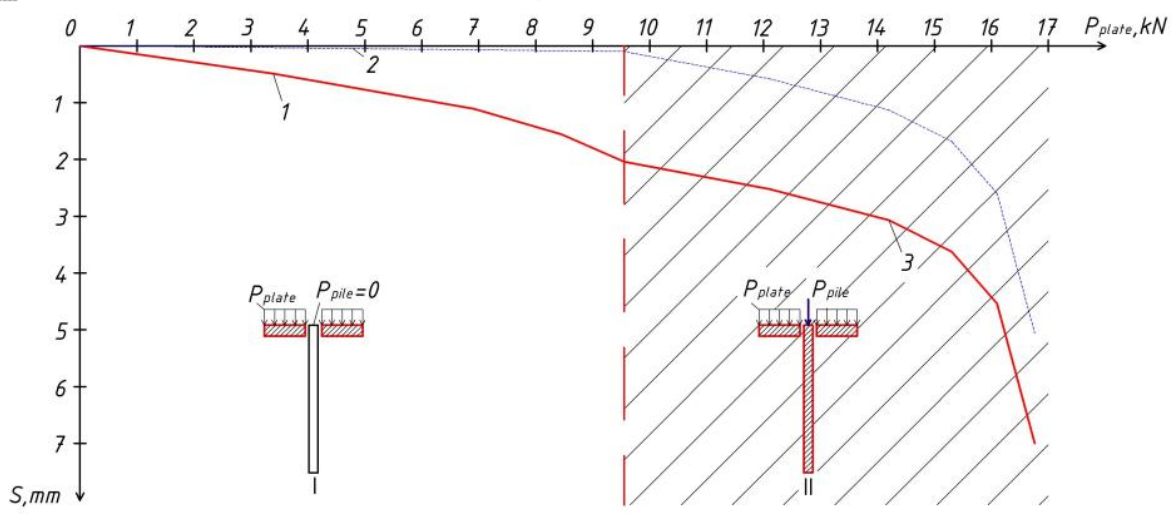

Fig. 6. Graph "Loading-Settlement". II ${ }^{\text {nd }}$ test of plate segments: $75 \mathrm{~mm}$ (a), $125 \mathrm{~mm}$ (b), $175 \mathrm{~mm}$ (c); 1 - plate settlement, 2 - pile settlement due to additional loading; 3 - settlement of plate joining a pile 
Pile shift $S_{\text {pile }}=0,03 \mathrm{~mm}$ due to compression around a pile as well as additional contact soil stress at some depth from a plate were evident when a $175 \mathrm{~mm}$ grillage segment was loaded (Fig. 6c).

\subsection{Third test. The elements of pile foundation segment were successively loaded, a pile joining a plate was additionally loaded.}

The III ${ }^{\text {rd }}$ test included 3 stages (Fig. 4 b,c,d). The $1^{\text {st }}$ stage was similar to plate loading in the $\mathrm{II}^{\text {nd }}$ test (Fig. $4 \mathrm{~b}$ ). The $2^{\text {nd }}$ stage is specific because, under some load on a plate, a pile was separately loaded until being settled $S_{\mathrm{n}} \approx 2 \mathrm{~mm}$ (Fig. $4 \mathrm{c}$ ). At the $3^{\text {rd }}$ stage, a pile joining a plate and a plate segment with a pile as a single construction was loaded (Fig. 4d).

Fig 7 shows dependence graphs $S=f(P)$ of the III $^{\text {rd }}$ test for three types of plate segments. Tests were conducted to reach maximum equal settlements: $S_{\text {plate+pile, }}$

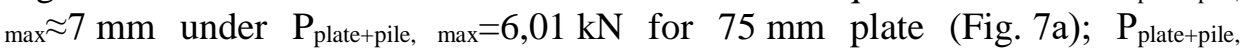
$\max =9,94 \mathrm{kN}$ for $125 \mathrm{~mm}$ plate (Fig. $7 \mathrm{~b}$ ); $\mathrm{P}_{\text {plate+pile, } \max }=17,33 \mathrm{kN}$ for $175 \mathrm{~mm}$ plate (Fig. 7c).

Pile shifts due to additional contact stress of soil around a pile were observed when plate segments of 125 and $175 \mathrm{~mm}$ diameter were loaded at the $2^{\text {nd }}$ stage of the III ${ }^{\text {rd }}$ test $($ Fig. $7 b, c)$. The bigger the diameter, the higher the area of additional contact soil stress around a pile. Moreover, maximum pile shift occurred when the $175 \mathrm{~mm}$ plate was loaded (Fig. 7c), whereas, a pile did not shift when a $75 \mathrm{~mm}$ plate was loaded.

a)

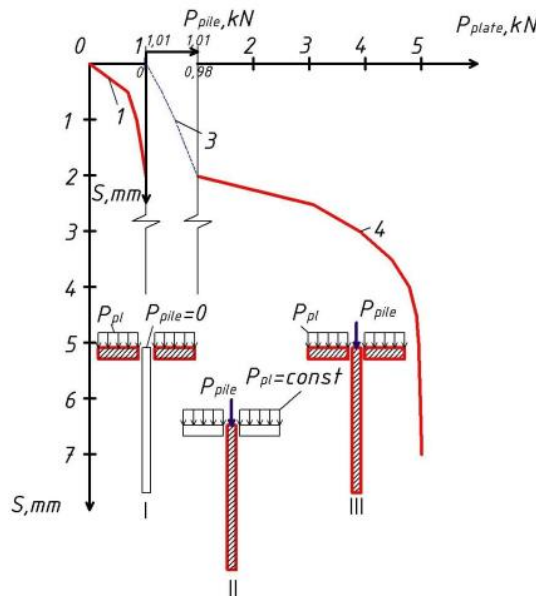

b)

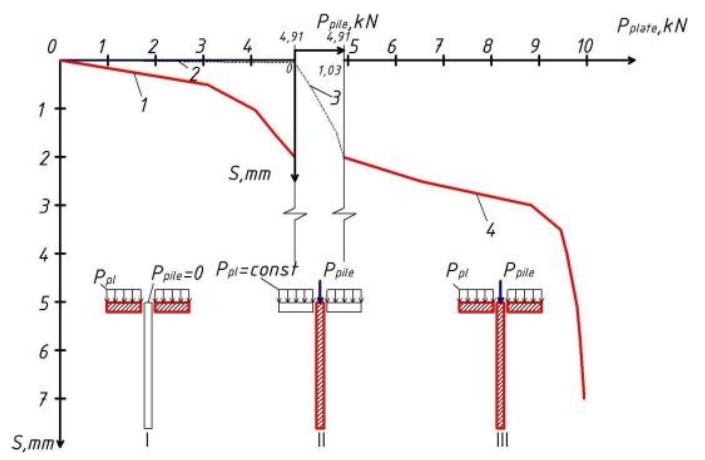


c)

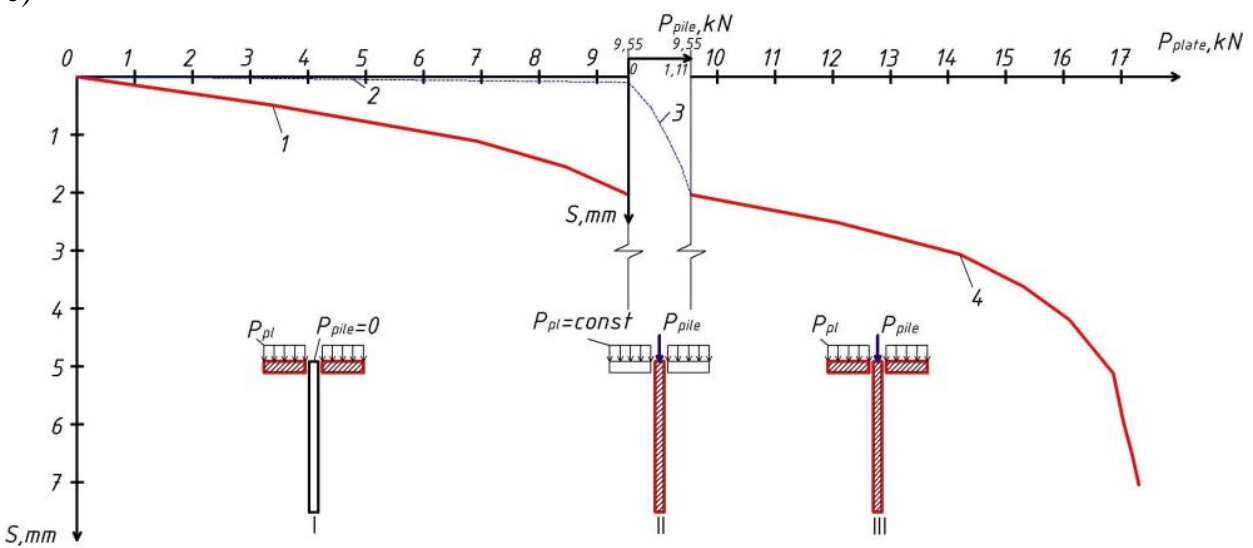

Fig. 7. Graph "Loading-Settlement". III ${ }^{\text {rd }}$ test of plate segments: $75 \mathrm{~mm}$ (a), $125 \mathrm{~mm}$

(b), $175 \mathrm{~mm}(\mathrm{c}) ; 1-1^{\text {st }}$ stage of plate settlement, $2-1^{\text {st }}$ stage of pile settlement; $3-2^{\text {nd }}$ stage of pile loading; $4-$ settlement of plate joining a pile

\section{CONCLUSIONS}

The findings of the $I^{s t}$ test allowed comparison of the results and making of an assessment since the segment performed as would a standard pile foundation and its stress and strain state was taken as $100 \%$ in our investigation.

Test results have shown that successive combined loading of elements in the $I I^{\text {nd }}$ test makes it possible for the foundation to bear more load: by $5 \%$ for a $75-\mathrm{mm}$ plate, by $8 \%$ for a $125-\mathrm{mm}$ plate, and by $4 \%$ for a $175-\mathrm{mm}$ plate.

The IIrd test with load combination, where a pile was additionally loaded, proved the capacity of bearing higher loads than in the $I I^{\text {nd }}$ test: by $10 \%$ for a $75-\mathrm{mm}$ plate, by $13 \%$ for a $125-\mathrm{mm}$ plate, and by $7 \%$ for a $175-\mathrm{mm}$ plate.

Load efficiency of pile foundation segments of different sizes is given in Table 1.

Table 1. the load percentage of pile foundation segments of different diameters

\begin{tabular}{|c|c|c|c|}
\hline $\begin{array}{l}\text { Plate diameter } \\
\text { Tests }\end{array}$ & $75 \mathrm{~mm}$ & $125 \mathrm{~mm}$ & $175 \mathrm{~mm}$ \\
\hline II & load more by $5 \%$ & load more by $8 \%$ & load more by $4 \%$ \\
\hline III & load more by $10 \%$ & load more by $13 \%$ & load more by $7 \%$ \\
\hline
\end{tabular}

It was proved experimentally under laboratory conditions that plate loading causes skin friction on some length of a pile side surface and provides its additional loading and shift. It also proved previous numerical modeling obtained in the investigation [1] and demonstrated the fact that the greater the square area of soil load is (different diameters of plates were used), the higher the friction effect (additional skin friction) of a pile not joining a plate is. 
Thus, successive application of pile foundation elements causes a base prestress state and can be useful, even before the structure load is applied, as well as providing additional load on a pile (reduces negative skin friction) and enhancing soil properties under the plate.

\section{BADANIA LABOLATORYJNE REDYSTRYBUCJISIŁ W PALACH POD OBCIĄŻENIEM POSZCZEGÓLNYCH JEGO CZĘŚCI}

\section{Streszczenie}

W prace zostały przedstawione wyniki badań laboratoryjnych redystrybucji sił w fundamencie palowym pod kolejnym obciążeniem poszczególnych jego elementów. Do badań został wykorzystany pojedynczy segment modelu fundamentu palowego. Obciążenia próbne segmentu przeprowadzono bez połączenia jego składowych (pali i płyty, która została przekształcona w ruszt) oraz w oparciu o różne kombinacje obciążenia statycznego elementów przy kolejnych połączeniach jego części. To udowodniło, że obciążenie płyty wpływa na wartość siły tarcia na pewnej długości pobocznicy pala, oraz prowadzi do dodatkowego obciążenia i osiadania pala. Wyniki badań pokazały, że zastosowanie etapowego łączenia składowych elementów fundamentu umożliwia zwiększenie obciążenia o 13\% względem zwykłej konstrukcji fundamentu palowego przy takim samym osiadaniu

Słowa kluczowe: badania laboratoryjne, nośność, pale fundamentowe

Editor received the manuscript: 02.10.2017 